\title{
Methane Emission and Milk Production from Jersey Cows Grazing Perennial Ryegrass-White Clover and Multispecies Forage Mixtures
}

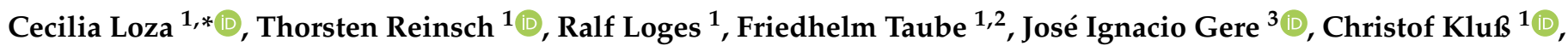 \\ Mario Hasler ${ }^{4}$ and Carsten S. Malisch ${ }^{1}$ (D) \\ 1 Institute of Plant Production and Plant Breeding, Grass and Forage Science/Organic Agriculture, \\ Christian-Albrechts Universität zu Kiel (CAU), Hermann-Rodewald Straße 9, 24118 Kiel, Germany; \\ treinsch@gfo.uni-kiel.de (T.R.); rloges@gfo.uni-kiel.de (R.L.); ftaube@gfo.uni-kiel.de (F.T.); \\ ckluss@gfo.uni-kiel.de (C.K.); cmalisch@gfo.uni-kiel.de (C.S.M.) \\ 2 Grass Based Dairy Systems, Animal Production Systems Group, Wageningen University (WUR), \\ 6700 AH Wageningen, The Netherlands \\ 3 Engineering Research and Development Unit (UTNBA), National Technological University, Regional School \\ of Buenos Aires, National Council for Scientific and Technical Research (CONICET), Ciudad Autónoma de \\ Buenos Aires Medrano 951 (C1179AAQ), Argentina; jgere@frba.utn.edu.ar \\ 4 Department of Statistics, Christian-Albrechts Universität zu Kiel (CAU), 24118 Kiel, Germany; \\ hasler@email.uni-kiel.de \\ * Correspondence: cloza@gfo.uni-kiel.de; Tel.: +49-431-880-2142
}

\section{check for} updates

Citation: Loza, C.; Reinsch, T.; Loges, R.; Taube, F.; Gere, J.I.; Kluß, C.; Hasler, M.; Malisch, C.S. Methane Emission and Milk Production from Jersey Cows Grazing Perennial Ryegrass-White Clover and Multispecies Forage Mixtures. Agriculture 2021, 11, 175. https:// doi.org/10.3390/agriculture11020175

Academic Editor:

Isabel Blanco-Penedo

Received: 22 January 2021

Accepted: 17 February 2021

Published: 20 February 2021

Publisher's Note: MDPI stays neutral with regard to jurisdictional claims in published maps and institutional affiliations.

Copyright: (c) 2021 by the authors. Licensee MDPI, Basel, Switzerland. This article is an open access article distributed under the terms and conditions of the Creative Commons Attribution (CC BY) license (https:/ / creativecommons.org/licenses/by/ $4.0 /)$.

\begin{abstract}
Methane is a major constituent of greenhouse gas (GHG) emissions from ruminants, and mitigation strategies are needed to alleviate this negative environmental impact while maintaining the environmental and other benefits of grazing systems. Forages containing plant-specialized metabolites (PSM), particularly condensed tannins, may help reduce enteric methane $\left(\mathrm{CH}_{4}\right)$ emissions. However, information on in vivo $\mathrm{CH}_{4}$ emissions from cows grazing mixtures that contain bioactive herbs is scarce. Accordingly, this study compared a binary mixture of perennial ryegrass (Lolium perenne) and white clover (Trifolium repens) against a diverse mixture of six additional species, including tannin-rich species like birdsfoot trefoil (Lotus corniculatus) and salad burnet (Sanguisorba minor), in a full-grazing dairy system. Enteric $\mathrm{CH}_{4}$ emissions were measured using the $\mathrm{SF}_{6}$ tracer technique. Cows grazing diverse mixtures increased their energy-corrected milk (ECM) yield by $4 \%(p<0.001)$ compared with binary mixtures. However, $\mathrm{CH}_{4}$ emissions per $\mathrm{kg}$ ECM were also $11 \%$ greater for the diverse mixtures $(p<0.05)$. The very high feed quality and milk yield from both mixtures explained the low $\mathrm{CH}_{4}$ emissions recorded relative to the milk output. The addition of forbs did not provide additional benefits at these intensities, as they were maintained in low yield shares throughout.
\end{abstract}

Keywords: polyphenols; climate smart agriculture; biodiversity; pasture; tannins; forage production

\section{Introduction}

Enteric methane $\left(\mathrm{CH}_{4}\right)$ is a byproduct of ruminal fermentation that allows the ruminal ecosystem to dispose of the metabolic hydrogen produced during microbial metabolism [1, 2]. This is problematic in terms of both agricultural utilization and environmental impact. Ruminal $\mathrm{CH}_{4}$ emissions represent a loss of feed energy through inefficient digestion. This is reported to be equivalent to 144 million tons of oil, globally, and enteric $\mathrm{CH}_{4}$ is responsible for $44 \%$ of the anthropogenic methane emissions [3]. Methane is a potent greenhouse gas, and it has been calculated that $20 \%$ of the radiative forcing since 1750 may be attributed to methane emissions [4]. However, despite this environmental impact, ruminants have an important role in supporting human nutrition and, unlike monogastrics, they have the evolutionary advantage of producing high-quality food (meats and milk) from grass. 
Thus, otherwise, marginal lands, including sites where other forms of agriculture cannot easily be supported, may be utilized by grazing to produce edible energy and protein for humans. Grasslands are also particularly important in providing ecosystem services, including climate change mitigation. This is linked particularly to their high carbon sequestration potential, with mean rates for the temperate conditions of $0.54 \mathrm{MgC} \mathrm{ha}^{-1} \mathrm{yr}^{-1}$ [5]. Other grassland-related ecosystem services include water purification and biodiversity enhancement [6]

The utilization of grasslands by grazing has also shown benefits in terms of the high quality of food products, notably through improved fatty acid profiles of milk and meats by increasing the conjugated linoleic acid (CLA) and polyunsaturated fatty acids (PUFA) concentrations, as compared with silage feeding; these attributes have potential benefits for human health [7-9]. Hence, grass-based dairy systems are considered to be not only highly competitive [10] but also beneficial for environmentally friendly and economically viable production $[10,11]$. Accordingly, grazing has been shown to be positively linked to consumer preference [12,13].

In the case of high-yielding dairy cows, it is important to determine the extent to which their metabolizable energy requirements can be met by forage. It has been wellestablished that energy intake is driven by a combination of forage quality (as determined by its fiber and protein contents) and the characteristics of the animals (breed, age, body weight, stage of lactation, and milk yield) that regulate the energy requirements and intake capacity [14-18]. In this way, the maximum energy intakes are achieved by the maximization of the nutrient concentration in the diet combined with a high feed intake. If the nutritional value of the forage is low, then, even with a high feed intake, the total energy intake will be insufficient to achieve the maximum output from high-performance cattle.

A meta-analysis by Peyraud and Delagarde [19] showed that high-quality forages (7.2-MJ Net Energy of Lactation (NEL) kg dry matter $\left(\mathrm{DM}^{-1}\right)$, on average) can meet the feed energy requirements of $400-\mathrm{kg}$ cows to produce $30 \mathrm{~kg}$ of fat-corrected milk (FCM) without supplementation. Similar levels of milk production could be also obtained from pastures with an herbage of lower energy content (6.5-6.8-MJ NEL kg DM${ }^{-1}$ ) and moderate concentrate supplementation (1.0-3.5 $\mathrm{kg} \mathrm{DM} \mathrm{day}^{-1}$ ).

However, poorly implemented grazing and pasture management can also result in increased nutrient losses [20] and reductions in digestibility of the herbage in the sward. This can lead to greater GHG emissions [21,22], thereby reducing the efficiency of forage utilization and overall sustainability of the system. A meta-analysis by Lorenz et al. [23] found that the forage efficiency has a significant effect on the carbon footprint of pasturebased systems, with low GHG emissions per product unit being achievable with improved grazing management, whereas the carbon footprint of $1 \mathrm{~kg}$ ECM milk can increase two to three-fold if the production system is inefficient. $\mathrm{As}_{\mathrm{CH}_{4}}$ is usually the major source of GHG emissions from dairy production, mitigation strategies are required that alleviate these negative impacts while also maintaining the benefits of grazing-based dairy production. The main factors determining $\mathrm{CH}_{4}$ emissions are: (a) the quantity and quality of the animal feed consumed, (b) the cattle breed and its yield of product (milk/meat), and (c) the composition of the rumen microbiome, with a focus on the methanogenic archaea. All these factors are interlinked, as the forage intake capacity is affected by the cattle breed and passage rates (which are also affected by the feed), while the feed determines the rumen microbiome and, again, the intake capacity. In those highly productive systems that have the lowest carbon footprints per liter of milk, there is little further potential in reducing emissions by feeding concentrates or using feed additives such as fats and oil seeds [24]. Consequently, the modification of the rumen microbiome has become the focus of research, including the use of halogen compounds and ionophores. However, as these are currently prohibited in the EU, it is the use of phytogenic substances and plants containing plant-specialized metabolites (PSM) such as tannins that may be considered as promising solutions to reduce $\mathrm{CH}_{4}$ emissions [25-28]. 
In particular, the potential of plants containing PSM is an interesting solution, as these species (a) may be incorporated into diets within both grazing and confinement systems, (b) may provide additional benefits for ecosystem services, such as potential increments in carbon immobilization $[29,30]$, and (c) provide animal health benefits, such as anthelmintic effects and frothy bloat prevention [31]. In the rumen, PSM and, particularly, proanthocyanidins (PAs) (syn. condensed tannins) bind with the dietary protein, protecting it from enzymatic hydrolysis, hence reducing the enteric methane production [26]. These complexes dissociate in the intestines at low $\mathrm{pH}$, thus enabling the protein to be absorbed. As well as suppressing $\mathrm{CH}_{4}$, this increases the concentration of utilizable protein at the duodenum ( $\mathrm{uCP}$ ) and, hence, enhances the forage nutritive value without depressing the rumen fiber digestion or daily intake [32,33]. These beneficial properties are dependent on both the concentration and structural composition of the PAs and, hence, are plant species-dependent [31,34,35]. Additionally, red clover contains polyphenol oxidase (PPO), which also has the potential to increase $\mathrm{uCP}$ and to increase the nitrogen use efficiency along the digestive tract [36].

Introducing herbs and legumes into mixtures for grasslands provides numerous benefits for productivity [37], yield stability [38], carbon inputs [39], and resource use efficiency as a result of the maximized complementarity in niche exploitation. However, these benefits do not necessarily continue indefinitely, and the forage quality of multispecies mixtures can be reduced due to difficulties in determining the optimal utilization timepoint as a result of differences in the maturation speed. There are also potential problems from introducing species if other aspects of their forage quality compare unfavorably to perennial ryegrass. Yet, if it were possible to combine the agronomic benefits of mixedspecies swards with the bioactive benefits due to additionally increased PSM contents in the pasture, this could substantially reduce the environmental impact of pasture-based dairy production. For this to be feasible, the plant species in a sward mixture need to be agronomically competitive and have a growth strategy adapted to grazing, in addition to properties for rumen bioactivity. If these attributes can be met, the target species could be included in sward mixtures with high yields and energy densities, while also alleviating negative externalities, such as methane emissions. Due to the limited persistence of many broad-leaved species, such as red clover and herbs, this potential is likely to be limited to ley systems of a maximum of two to three years [37]. Information on methane emissions from cow grazing mixtures, including bioactive herbs, is scarce, and almost all information has been obtained from in vitro studies using the herbs only or herb extracts $[40,41]$.

Therefore, we designed an in vivo experiment based on the $\mathrm{SF}_{6}$ tracer technique [42] on an intensive pasture-based dairy farm to identify the potential for increased pasture diversity, using herbs containing PSM with the potential to lower the $\mathrm{CH}_{4}$ emissions per $\mathrm{kg}$ of milk.

We hypothesized that:

I. Diverse mixtures, including species rich in PSM and PPO-rich red clover (RC), will improve the protein use efficiency, thus increasing milk yields.

II. The inclusion of PSM-rich legumes and herbs will reduce the methane intensity $\left(\mathrm{g} \mathrm{CH}_{4}\right.$ $\mathrm{kg} \mathrm{FCM}^{-1}$ ) as a result of both the increased milk yield and the anti-methanogenic effect from polyphenols.

III. Despite the increased species number, diverse mixtures would not decrease the energy yields compared to binary mixtures if the grazing intervals are short enough to provide only material with high digestibility.

\section{Materials and Methods}

The experiment was conducted at the Lindhof experimental farm in Northern Germany $\left(54^{\circ} 27^{\prime} 56.0^{\prime \prime} \mathrm{N} 9^{\circ} 57^{\prime} 56.0^{\prime \prime}\right.$ E) from March to September 2019. The climate at the Lindhof is temperate maritime $\left(8.7^{\circ} \mathrm{C}\right.$ and $785-\mathrm{mm}$ annual means, 1981-2010), and soil types vary between Cambisols, Luvisols, Stagnosols, and Coluvic Regosols. The soil texture at the experimental site is sandy loam and loamy sand. 


\subsection{Weather Conditions}

According to Germany's National Meteorological Service (Deutscher Wetterdienst (DWD)), mean temperatures for the "Kiel-Holtenau" weather station were $1.3^{\circ} \mathrm{C}$ below the 30-year average (1981-2010) in both of the experimental periods (P1 and P2) during the year (Table 1). Accumulated rainfall was greater $(+16 \mathrm{~mm})$ than the long-term average for P1 and lower than the 30-year average for P2 $(-9 \mathrm{~mm})$.

Table 1. Mean temperature and cumulative precipitation during the experimental months (May and August) in the experimental year 2019 and the 30-year average.

\begin{tabular}{ccccc}
\hline & \multicolumn{2}{c}{ Mean Temp $\left({ }^{\circ} \mathbf{C}\right)$} & \multicolumn{2}{c}{ Rain (mm) } \\
\hline & $\mathbf{2 0 1 9}$ & $\mathbf{1 9 8 1 - 2 0 1 0}$ & $\mathbf{2 0 1 9}$ & $\mathbf{1 9 8 1 - 2 0 1 0}$ \\
\hline May (P1) & 10.6 & 11.9 & 70.4 & 54.0 \\
August (P2) & 17.0 & 18.3 & 74.0 & 82.5 \\
\hline
\end{tabular}

\subsection{Pasture and Grazing Management}

The Lindhof grazing system is arranged as a two-year grass-clover ley system in an organic 4-year crop rotation (2 years of grass-clover, followed by 2 years of crops: oats/winter triticale and faba beans/winter spelt, consecutively). As the site is under organic management, no mineral $\mathrm{N}$ fertilization is added, but limestone, rock phosphate, and potassium sulphate are applied in biannual intervals. The average soil nutrient contents at 0-30-cm-depths were 19.4- $\mathrm{g}_{2} \mathrm{O}_{5}, 17.6-\mathrm{g} \mathrm{K}{ }_{2} \mathrm{O}$, and $12.0 \mathrm{~g} \mathrm{Mg}$ per 100-g dry soil; the $\mathrm{pH}$ was 6.2 , and the average $\mathrm{C} / \mathrm{N}$ ratio was 10.9 .

The experimental grazing area comprised two paddocks of approx. 2.2 ha per treatment subdivided into daily strips, grazed successively. A new strip was offered to the cows after each morning of milking. Back grazing was prevented by electric fencing. The area of each strip was calculated based on the available pregrazing herbage mass (HM) and the established daily allowance. The target forage allowances for the experimental swards were 18 and 14-kg DM per cow and day for P1 and P2, respectively, and the target residue was generally set at 4-kg DM per cow and per day. The composition and sowing rate of the experimental sward is given in Table 2.

Table 2. Composition and sowing rate $\left(\mathrm{kg} \mathrm{ha}^{-1}\right)$ of the binary and diverse seed mixtures used in the experiment.

\begin{tabular}{cccccc}
\hline Species & Variety & Ploidy & & \multicolumn{2}{c}{ Seed Mixture } \\
\hline & & & Abbr ${ }^{\mathbf{1}}$ & Binary & Diverse \\
\hline & Discus & $2 \mathrm{n}^{2}$ & PRG & 6.0 & 4.0 \\
Perennial ryegrass (Lolium perenne) & Calvano1 & $2 \mathrm{n}$ & PRG & 6.0 & 4.0 \\
& Astonenergy & $4 \mathrm{n}^{3}$ & PRG & 6.0 & 4.0 \\
White clover (Trifolium repens) & Astonhockey & $4 \mathrm{n}$ & PRG & 6.0 & 4.0 \\
& Vysocan & & WC & 2.0 & 0.65 \\
Red clover (Trifolium pratense) & Liflex & & WC & 2.0 & 0.65 \\
& Harmonie & 2n & RC & - & 1.5 \\
Ribwort plantain & Larus & $4 \mathrm{n}$ & RC & - & 1.5 \\
(Plantago lanceolata) & "native" & & LP & - & 1.0 \\
Chicory (Cichorium intybus) & Spadona & & CI & - & 2.0 \\
Salad burnet (Sanguisorba minor) & Burnet & & SB & - & 2.0 \\
Caraway (Carum carvi) & Volhouden & & CC & - & 2.0 \\
Birdsfoot trefoil (Lotus corniculatus) & Lotanava & & BFT & - & 3.0 \\
\hline
\end{tabular}

${ }^{1}$ Abbreviation of each species used in this experiment. ${ }^{2}$ n: diploid cultivars. ${ }^{3} 4 \mathrm{n}$ : tetraploid cultivars.

Five weeks prior to the first measurement period, all animals started grazing on the same paddocks, which were a selection of both the binary and diverse mixture (for details, 
see Table 2). This procedure was applied to ensure the adaptation of the ruminal microbiota to a pasture-based diet and to all species that were subsequently included in the treatments.

\subsection{Animals, Experimental Design, and Treatment}

Animal procedures were conducted in accordance with the German Animal Welfare Act (TierSchG) and were authorized by the Animal Welfare Commission of the Ministry of Energy, Agriculture, Environment, and Rural Areas of the Federal State of SchleswigHolstein, Germany (V 242-32938/2018). Twenty-four multiparous lactating Jersey cows were selected for the experiment. On average $( \pm S D)$, they had pre-experimental milk yields of $17.4 \pm 2.7 \mathrm{~kg}$ day $^{-1}$, days in milk (DIM) of $45 \mathrm{~d} \pm 28$, body weights of $448 \mathrm{~kg} \pm 51$, and parities of $3 \pm 1$. For the measurement periods, the animals were grouped into homogeneous pairs, based on all the above-mentioned factors, one of which was assigned randomly to each of the two groups to create comparable subgroups. The experimental periods were conducted using a balanced crossover design (two treatments $\times$ two subperiods, with each subperiod consisting of 4 days of adaptation followed by 4 days of measurements). As both mixtures were grazed by all cows for at least the previous 5 weeks, the rumen biome was considered to be stable and adjusted to both mixtures. Based on the observed metabolic plasticity of the rumen microbes, the four days were then considered to be sufficient for the stable and preadapted microbes to adapt to the specific substrate and shift the formation of the fermentation products accordingly [43]. All the cows were given $2 \mathrm{~kg}( \pm 0.5)$ of concentrate (mixture of faba bean, triticale, lupins, and maize) on a fresh matter basis per day, in two feedings, during milking. Details of the compositions of the seed mixtures representing the two treatments in this experiment are detailed in Table 2.

\subsection{Herbage Measurements}

Due to the research farm being certified as organic in accordance with EU standards (Regulation (EC) No 834/2007), as well as in accordance with the stricter regulations of the "Bioland" certification (the largest organic food association in Germany), the use of tracers of any kind to measure grass intake is prohibited. As this prevents the measuring of individual feed intake in the grazing animals, the individual DM intake (DMI) for each cow and subperiod was estimated according to the model developed by Gruber et al. [44] based on the days in milk (DIM), cow breed, parity, body weight (BW), and milk yield (MY). Gruber et al. [44] was selected after the assessment of the performance of four different models, having provided the most accurate results [45]. To validate the model for the experimental conditions, the biomass on offer and residues were measured using both an electronic rising platemeter (Grasshopper, True North Technologies, Shannon, Ireland), taking 100 measurements per treatment made at random intervals while traversing the plot in a zigzag across each grazing area and by cutting ten randomly chosen quadrats of $0.25 \mathrm{~m}^{2}$ per treatment to a height of $4 \mathrm{~cm}$ by means of hand-operated grass clippers. These methods allowed the calculation of a group intake and, thus, a calculation of the average consumption per cow. The cut samples were subsequently sorted to determine the botanical composition. For this procedure, each sample was collected in plastic bags and weighed immediately after cutting. From the hand-cut samples, a 100-g subsample was taken for hand separation to determine the botanical composition. Unsown species were collected separately. All fractions were weighed and dried at $58{ }^{\circ} \mathrm{C}$ for $48 \mathrm{~h}$. After drying, samples were weighed for DM determination and milled to a particle size of $1 \mathrm{~mm}$ (Ultracentrifugal mill, ZM200, Retsch GmbH, Haan, Germany) for chemical analysis. Forage use efficiency (FUE) was estimated as the difference between the offered and the remaining herbage, as determined by the cut quadrats, according to the following equation:

Forage use efficiency $(\%)=$ (offered herbage - remaining herbage)/offered herbage, where offered herbage is the herbage offered to the cows before grazing, and remaining herbage is the herbage remaining after grazing, both expressed in $\mathrm{kg} \mathrm{DM} / \mathrm{ha}$. 


\subsection{Animal Measurements}

Throughout the study, cows were milked twice a day (6 a.m. and 4 p.m.) (DeLaval MPC 680, DeLaval AB Tumba, Sweden) and individual milk yield was recorded automatically (DeLaval MM15, DeLaval AB Tumba, Sweden) every time, during 4 consecutive days (d5 to $\mathrm{d} 8$ of each subperiod, for both periods). Milk composition (fat, protein, and lactose) was determined daily from morning and afternoon milk samples (d5 to d8 of each subperiod), and energy-corrected milk (ECM) was estimated according to Sjaunja [46] as: $\mathrm{ECM}=\mathrm{MY} \times(0.2534+0.1226 \times$ fat $+0.0776 \times$ protein $)$, where MY is the measured milk yield $\left(\mathrm{kg}\right.$ cow day $\left.{ }^{-1}\right)$, and fat and protein are the daily concentrations (\%) of fat and protein, respectively. Body weight was recorded on each day of the experimental period after each milking. Variation in BW was calculated as the difference of the individual mean weight at the beginning and the end of each period.

Enteric $\mathrm{CH}_{4}$ emissions were measured using the $\mathrm{SF}_{6}$ tracer technique following the manual of Global Research Alliance for Greenhouse Gases on Agriculture [47] and using the adaptation of Gere and Gratton [42] for a 4-day collection period. Seven days prior to the beginning of the first measurements, a precalibrated $\mathrm{SF}_{6}$ permeation tube was introduced per os into the rumen of each cow using a plastic dosing applicator. The mean permeation rate of the $\mathrm{SF}_{6}$ capsules used in this experiment was $4.5 \pm 0.97 \mathrm{mg} \mathrm{d}^{-1}$. Permeation rates were validated gravimetrically by serial weighing of the $\mathrm{SF}_{6}$ permeation tubes (kept at $39^{\circ} \mathrm{C}$ (the nominal rumen temperature in cattle) in a water bath) with an analytical balance over a period of $\sim 6$ weeks. Only capsules with $R^{2}$ values exceeding 0.9995 were selected to be used in the experiment. The sampling system for the collection of the exhaled air consisted of 0.5-L canisters (made of stainless steel or polyvinyl chloride (PVC)) and a ball baring inflow restrictor adjusted to accumulate 0.5 bar of air sample during a 4-day period (d5 to $\mathrm{d} 8$ of each subperiod) and a 6-mm $\varnothing$ polyethylene (PE) tube, used to connect both. The gas sampling tube was protected by a flexible PVC tube (16-mm inner Ø). The inflow restrictor was protected against water and dust by a double filter [42] and was located above the animal's nostrils, using a canvas halter adapted for this purpose. To ensure the comfort of the cows, as well as the reliability of the sampling, two canisters were fitted on the back of each cow using a foam-filled canvas belt, also adapted for this purpose. Each belt was mounted between the shoulders and hipbones and secured using an adjustable leather strap extending from the top of the belt to a padded strap around the base of the cows' tail. Simultaneously (d5 to d8), background air samples were collected at two points in each experimental plot, using the same system as for the breath samples. Immediately prior to the sampling period, each collecting canister was evacuated $(<0.5 \mathrm{mb})$ after being cleaned with high-purity nitrogen gas $\left(\mathrm{N}_{2}\right)$. The exhaled and background air samples collected were analyzed for concentrations of $\mathrm{CH}_{4}$ (ppm, parts per million by volume) and $\mathrm{SF}_{6}$ (ppt, parts per trillion by volume) by gas chromatography (SCION 456-GC, Bruker, Leiderdorp, The Netherlands) immediately after the end of each measuring period. The method was calibrated using four $\mathrm{CH}_{4}$ standards (Linde $\mathrm{GmbH}$, Pullach, Germany) with defined concentrations, as well as a 10-point dilution curve of an $\mathrm{SF}_{6}$ standard (Linde $\mathrm{GmbH}$, Pullach, Germany), covering the entire expected range of $\mathrm{SF}_{6}$ concentrations in the samples. After correction for background gas concentrations, the daily $\mathrm{CH}_{4}$ emissions were calculated according to the following equation from Gere and Gratton [42]: $\mathrm{Q}_{\mathrm{CH} 4}=$ $\mathrm{QSF}_{6} \times\left(\left[\mathrm{CH}_{4}\right] /\left(\left[\mathrm{SF}_{6}\right]\right)\right.$, where $\mathrm{Q}_{\mathrm{CH} 4}$ is the daily methane emission $\left(\mathrm{g} \mathrm{d}^{-1}\right)$, $\mathrm{QSF}_{\mathrm{SF}}$ is the $\mathrm{SF}_{6}$ permeation rate of the inserted capsules, and $\left[\mathrm{CH}_{4}\right]$ and $\left[\mathrm{SF}_{6}\right]$ are the concentrations of these gases above the atmospheric concentration.

\subsection{Chemical Analysis}

Forage quality parameters of all samples were determined by near-infrared reflectance spectroscopy (NIRS) with a NIRSystems 5000 monochromator (FOSS, Laurel, MD, USA). Mathematical evaluation of the spectra was performed using the Modified Partial Least Squares method (WinISI software version 3, Infrasoft International, Mumbai, MH, India). 
Calibration and validation were based on sample subsets of perennial ryegrass, legumes, and forage herb species, which represented the whole spectral and chemical variability.

The following analyses of the subset samples were performed as follows: The $\mathrm{N}$ concentration was directly determined with an elemental analyzer (Vario Max CN, Elementar Analysensysteme, Hanau, Germany); the crude protein content (CP) was calculated from the $\mathrm{N}$ content $(\mathrm{CP}=\mathrm{N} \cdot 6.25)$. The concentrations of NDF (assayed with heat-stable amylase $(\mathrm{aNDF})$ ) and ADF were analyzed using the Fiber Analyzer Ankom A2000 (Ankom Technology, Macedon, NY, USA). The ADF values were expressed exclusive from the residual ash (ADFom). Ash (A) was determined by combustion in a muffle furnace $\left(24 \mathrm{~h}\right.$ at $\left.550{ }^{\circ} \mathrm{C}\right)$. Digestibility and metabolizable energy (ME) content of herbage samples was determined using the in vitro cellulase technique developed by De Boever, Cottyn [48]. The percentage of digestible organic matter (DOM) was calculated using the enzymatic soluble organic matter (ELOS) and the enzymatic insoluble organic matter (EULOS).

The following equations were used:

$$
\begin{aligned}
& \operatorname{DOM}(\%)=100 \times\left(940-\mathrm{A}-0.62 \times \operatorname{EULOS}-0.000221 \times[\mathrm{EULOS}]^{\wedge} 2\right) /(1000-\mathrm{A}) \\
& \text { EULOS }\left(\mathrm{g} \mathrm{kg}^{-1} \mathrm{DM}\right)=1000-\mathrm{A}-\mathrm{ELOS} \\
& \operatorname{ME}\left(\mathrm{MJ} \mathrm{kg}^{-1} \mathrm{DM}\right)=5.51+0.00828 \times \text { ELOS }-0.00511 \times \mathrm{A}+0.02507 \times \mathrm{CL}-0.00392 \times \mathrm{ADFom}
\end{aligned}
$$

The net energy lactation content was derived from the metabolizable energy content (ME) and was estimated using the following equation: NEL $\left(\mathrm{MJ} \mathrm{kg}{ }^{-1} \mathrm{DM}\right)=\mathrm{ME}(0.46+$ 12.38 ME/(1000 - A).

The statistical key figures of the NIRS calibration and validation are given in Table A1 of the Appendix A.

The concentrations of $\mathrm{CH}_{4}$ and $\mathrm{SF}_{6}$ were determined by gas chromatography (SCION 456-GC, Bruker, Leiderdorp, The Netherlands). The samples were injected in two different setups: a 3-mL loop, a HP-PLOT Q column, and a flame ionization detector (FID) for $\mathrm{CH}_{4}$ and a 10-mL loop, a HP-MOLSIV column, and an electron capture detector (ECD) for $\mathrm{SF}_{6}$. Each sample was analyzed at least twice, and the average values were used to obtain the $\mathrm{CH}_{4}$ concentration and $\mathrm{CH}_{4}$ emissions. The maximum delay between the collection and the determination of the $\mathrm{CH}_{4}$ and $\mathrm{SF}_{6}$ concentrations was 15 days.

\subsection{Statistical Analysis}

All experimental data were analyzed with statistical software R [49].

Sward characteristics and chemical composition for pre- and post-grazing HM were analyzed with ANOVA followed by multiple contrast tests, using a linear mixed model, including the treatment (i.e., the mixture) and period (spring vs. autumn) and their interaction as fixed factors and the date of sampling within each subperiod as the random factor.

Milk data were also analyzed with ANOVA followed by multiple contrast tests, using a linear mixed model, including the treatment (i.e., the mixture) and period (May vs. August) and their interaction as fixed factors. However, the random factor was the experimental period nested in the individual cow. Additionally, the correlations of the measurement values due to the repeated measurements of each individual cow were considered.

The same model was also used for the methane data, without the correlation factor, however, as the methane values were sampled cumulatively over the sampling period.

All models were analyzed as split-plot designs. Based on graphical residual analyses, data were assumed to be normally distributed and heteroscedastic.

\section{Results}

\subsection{Methane Emissions and Sward Characteristics}

Information regarding the sward yield and quality are shown in Table 3. The mean values of the herbage mass per ha did not differ between treatments for P1 and was $2308-\mathrm{kg}$ DM. However, it was significantly greater $(p<0.001)$ for the diverse mixture 
compared to the binary mixture in P2, with 1218- and 677-kg DM ha ${ }^{-1}$, respectively. The paddock sizes were adjusted accordingly to provide an equal herbage mass on offer per cow. The FUE was similar between treatments over both periods, yet with a nonsignificant tendency of a greater FUE in the diverse pasture.

Table 3. Forage characteristics, milk production, target daily herbage availability, DM intake, herbage utilization, methane emissions, and body weight (BW) variation of dairy cows grazing on binary and diverse mixtures. Abbreviations are as follows (sorted alphabetically): ADF: acid detergent fiber, CP: crude protein, DHA: daily herbage allowance, DMI: dry matter intake, ECM: energy-corrected milk, FUE: forage use efficiency, HM: herbage mass, ME: metabolizable energy, NDF: neutral detergent fiber, and NEL: net energy for lactation.

\begin{tabular}{|c|c|c|c|c|}
\hline & \multicolumn{2}{|c|}{ P1 (2-8 May 2019) } & \multicolumn{2}{|c|}{ P2 (15-30 August 2019) } \\
\hline & Binary & Diverse & Binary & Diverse \\
\hline & Mean (SEM) & Mean (SEM) & Mean (SEM) & Mean (SEM) \\
\hline \multicolumn{5}{|l|}{ Forage characteristics } \\
\hline $\mathrm{HM}\left(\mathrm{kg} \mathrm{DM} \mathrm{ha} \mathrm{a}^{-1}\right)$ & $2460(177) \mathrm{Aa}$ & $2157(68) \mathrm{Aa}$ & $677(95)^{\mathrm{Bb}}$ & $1218(151){ }^{\mathrm{Aa}}$ \\
\hline OM digestibility & $87.6(0.25) \mathrm{Aa}$ & $84.4(0.17)$ Ва & $80.2(0.36) \mathrm{Ab}$ & $77.9(0.44)^{\mathrm{Bb}}$ \\
\hline $\mathrm{ME}\left(\mathrm{MJ} \mathrm{kg} \mathrm{DM}{ }^{-1}\right)$ & $12.5(0.03) \mathrm{Aa}$ & $12.1(0.01) \mathrm{Ba}$ & $11.3(0.09) \mathrm{Ab}$ & $11.1(0.05)^{\mathrm{Bb}}$ \\
\hline NEL $\left(\mathrm{MJ} \mathrm{kg} \mathrm{DM}^{-1}\right)$ & $7.7(0.01) \mathrm{Aa}$ & $7.5(0.01) \mathrm{Ba}$ & $6.9(0.06) \mathrm{Ab}$ & $6.7(0.03)^{\mathrm{Bb}}$ \\
\hline \multicolumn{5}{|l|}{ Chemical composition $\left(\mathrm{g} \mathrm{kg}^{-1}\right)$} \\
\hline $\mathrm{CP}$ & $11.5(0.52) \mathrm{Ba}$ & $15.6(0.14) \mathrm{Aa}$ & $18.5(0.79) \mathrm{Bb}$ & $20.3(0.51) \mathrm{Ab}$ \\
\hline NDF & $35.5(0.29) \mathrm{Ba}$ & $38(0.30) \mathrm{Aa}$ & $49.9(0.66)^{\mathrm{Bb}}$ & $45.3(0.46) \mathrm{Ab}$ \\
\hline $\mathrm{ADF}$ & $16.6(0.20) \mathrm{Ba}$ & $19.5(0.17) \mathrm{Aa}$ & $22.8(0.40)^{\mathrm{Bb}}$ & $26.7(0.33) \mathrm{Ab}$ \\
\hline Fat & $2.7(0.1)^{\mathrm{Bb}}$ & $3.1(0.05) \mathrm{Aa}$ & $4.1(0.08) \mathrm{Aa}$ & $3.6(0.06)^{\mathrm{Ba}}$ \\
\hline \multicolumn{5}{|l|}{ Milk production } \\
\hline Days in milk & $49(28)$ & $49(28)$ & $154(26)$ & $154(26)$ \\
\hline Milk yield ( $\mathrm{kg} \mathrm{cow}^{-1}$ day $\left.^{-1}\right)$ & $23.4(0.77) \mathrm{Ba}$ & $24.9(0.86) \mathrm{Aa}$ & $18.6(0.71)^{\mathrm{Bb}}$ & $19.8(0.66) \mathrm{Ab}$ \\
\hline ECM yield $\left(\mathrm{kg} \mathrm{cow}^{-1}\right.$ day $\left.^{-1}\right)$ & $29.4(0.91) \mathrm{Ba}$ & $30.3(0.98) \mathrm{Aa}$ & $22.1(0.61)^{\mathrm{Bb}}$ & $23.5(0.64) \mathrm{Ab}$ \\
\hline \multicolumn{5}{|l|}{ Milk composition } \\
\hline Fat content $\left(\mathrm{g} \mathrm{kg} \mathrm{DM}^{-1}\right)$ & $59.2(1.09) \mathrm{Aa}$ & $56.6(1.08) \mathrm{Ba}$ & $53.6(1.19) \mathrm{Bb}$ & $53.7(1.08) \mathrm{Ab}$ \\
\hline Protein content $\left(\mathrm{g} \mathrm{kgDM}^{-1}\right)$ & $35.7(0.60) \mathrm{Ab}$ & $35.1(0.51) \mathrm{Bb}$ & $38.0(0.71) \mathrm{Aa}$ & $36.8(0.66) \mathrm{Ba}$ \\
\hline Lactose content $\left(\mathrm{g} \mathrm{kgDM}^{-1}\right)$ & $47.9(0.19) \mathrm{Aa}$ & $46.0(0.21) \mathrm{Ba}$ & $45.8(0.17) \mathrm{Ab}$ & $44.7(0.17)^{\mathrm{Bb}}$ \\
\hline Fat yield $\left(\mathrm{kg}\right.$ day $\left.^{-1}\right)$ & $1.38(0.05) \mathrm{Ba}$ & $1.41(0.05) \mathrm{Aa}$ & $0.98(0.03) \mathrm{Ba}$ & $1.05(0.03) \mathrm{Ba}$ \\
\hline Protein yield (kg day $\left.{ }^{-1}\right)$ & $0.83(0.02) \mathrm{Ba}$ & $0.87(0.03) \mathrm{Aa}$ & $0.69(0.02) \mathrm{Ba}$ & $0.71(0.02) \mathrm{Ba}$ \\
\hline Lactose yield (kg day $\left.{ }^{-1}\right)$ & $1.12(0.04) \mathrm{Ba}$ & $1.15(0.04) \mathrm{Aa}$ & $0.85(0.03) \mathrm{Ba}$ & $0.89(0.03) \mathrm{Ba}$ \\
\hline 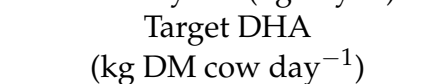 & \multicolumn{3}{|c|}{$\left(\mathrm{kg}\right.$ DM cow day $\left.{ }^{-1}\right)$} & 14 \\
\hline$\left(\operatorname{kg~DM~cow~day~}^{-1}\right)^{1}$ & \multicolumn{3}{|c|}{$\left(\mathrm{kg} \mathrm{DM} \mathrm{cow} \mathrm{day}^{-1}\right)^{1}$} & 11.5 \\
\hline $\begin{array}{c}\text { DMI } \\
\left(\operatorname{kg~DM~cow~day~}^{-1}\right)^{2}\end{array}$ & 13.0 & 15.0 & 10.6 & 13.0 \\
\hline FUE $(\%)$ & 58 & 66 & 69 & 77 \\
\hline \multicolumn{5}{|l|}{ Methane emissions } \\
\hline $\mathrm{g} \mathrm{CH}_{4} \mathrm{cow}^{-1} \mathrm{day}^{-1}$ & $239(8) \mathrm{Bb}$ & $277(11)$ Аa & $203(8)^{\mathrm{Bb}}$ & $242(15) \mathrm{Aa}$ \\
\hline $\mathrm{g} \mathrm{CH}_{4} \mathrm{~kg} \mathrm{milk}^{-1}$ & $10.4(0.4) \mathrm{Ba}$ & $11.2(0.4) \mathrm{Aa}$ & $11.2(0.4) \mathrm{Ba}$ & $12.6(0.8) \mathrm{Aa}$ \\
\hline $\mathrm{gCH}_{4} \mathrm{~kg} \mathrm{ECM}^{-1}$ & $8.3(0.4) \mathrm{Bb}$ & $9.2(0.3) \mathrm{Aa}$ & $9.3(0.6) \mathrm{Bb}$ & $10.4(0.3)$ Аа \\
\hline $\mathrm{g} \mathrm{CH}_{4} \mathrm{~kg} \mathrm{DMI}^{-1}$ & 14.3 & 16.5 & 17.7 & 21 \\
\hline BW variation $\left(\mathrm{kg}\right.$ day $\left.^{-1}\right)$ & $-0.2^{\mathrm{Aa}}$ & $-0.3^{\mathrm{Aa}}$ & $0.1^{\mathrm{Aa}}$ & $0.3^{\mathrm{Aa}}$ \\
\hline
\end{tabular}

${ }^{1}$ Estimated according to Gruber et al. (2004) and includes 2-kg concentrate. ${ }^{2}$ Estimated with pre- and post-grazing measurements of the herbage mass in addition to $2 \mathrm{~kg}$ of concentrate. ${ }^{\mathrm{A}, \mathrm{B}}$ Differences between treatment, according to the adjusted $p$-value method. $\mathrm{a}, \mathrm{b}$ Differences between the periods, according to the adjusted $p$-value method.

The chemical composition of both herbage mixtures on offer generally identified a high quality for both mixtures across $\mathrm{P} 1$ and $\mathrm{P} 2$, despite decrements over time. On average, across $\mathrm{P} 1$ and $\mathrm{P} 2$, the organic matter digestibility (OMD) and energy content (ME and NEL) mean values of the binary mixture were $3.5 \%$ greater $(p<0.001)$ than that of the diverse mixtures. In contrast, the crude protein and ADF contents were, on average, $\sim 15 \%$ lower $(p<0.001)$ for the binary mixtures across both periods. 
The botanical composition of the offered forage is shown in Table 4. Perennial ryegrass was the predominant species in both swards. When comparing the botanical composition of the residual swards after grazing with that of the offered forage, a positive selection by grazing animals for the herb species in diverse mixtures could be identified, with herb shares decreasing by $66 \%$ in $\mathrm{P} 1$ and $55 \%$ in $\mathrm{P} 2$ when compared to the offered herbage. The preference for white clover was intermediate, and perennial ryegrass was the leastpreferred species by the cows in this mixture. In the binary mixtures, the data indicate a preference towards white clover over perennial ryegrass.

Table 4. Botanical composition (\%) of the offered (Offer) and remaining (rest) herbage for the binary and diverse mixtures during both experimental periods. Abbreviations are as follows: PRG: perennial ryegrass, WC: white clover, RC: red clover, and BFT: birdsfoot trefoil.

\begin{tabular}{|c|c|c|c|c|c|c|c|c|}
\hline & \multicolumn{4}{|c|}{ P1 (2-18 May 2019) } & \multicolumn{4}{|c|}{ P2 (15-30 August 2019) } \\
\hline & \multicolumn{2}{|c|}{ Binary } & \multicolumn{2}{|c|}{ Diverse } & \multicolumn{2}{|c|}{ Binary } & \multicolumn{2}{|c|}{ Diverse } \\
\hline & Offer & Rest & Offer & Rest & Offer & Rest & Offer & Rest \\
\hline & Mean (SEM) & Mean (SEM) & Mean (SEM) & Mean (SEM) & Mean (SEM) & Mean (SEM) & Mean (SEM) & Mean (SEM) \\
\hline PRG & $87.1(2.0)^{a B x}$ & $96.4(0.6)$ aBy & $43.1(2.2)^{\mathrm{aAx}}$ & $74.0(1.2)$ aAy & $51.6(3.3)^{a B x}$ & $61.1(3.4)^{a B y}$ & $25.4(2.2)^{\mathrm{aAx}}$ & $36.8(2.6)^{\mathrm{aAx}}$ \\
\hline WC & $12.5(2.0)^{\mathrm{aAx}}$ & $3.1(0.5)^{\mathrm{aBy}}$ & $15.0(1.5)^{\mathrm{aAx}}$ & $7.5(0.7)^{\mathrm{aAy}}$ & $47.6(3.2)^{a B x}$ & 36.9 (3.3) ${ }^{a B y}$ & $20.4(2.0)^{\mathrm{aAx}}$ & $17.9(1.7)^{\mathrm{aAx}}$ \\
\hline $\mathrm{RC}$ & - & - & $18.0(1.8)^{a x}$ & $9.9(1.0)^{\text {ay }}$ & - & - & $40.4(2.5)^{a x}$ & $36.5(2.9)^{a x}$ \\
\hline BFT & - & - & $7.0(0.9)^{a x}$ & $2.2(0.4)$ ay & - & - & $3.6(0.8)^{a x}$ & $2.6(0.5)^{a x}$ \\
\hline $\mathrm{LP}$ & - & - & $8.6(1.0)^{a x}$ & $3.8(0.6)$ ay & - & - & $4.0(0.7) a x$ & $2.6(0.7) a x$ \\
\hline $\mathrm{CI}$ & - & - & $7.5(1.3)^{a x}$ & $1.9(0.3)^{\text {ay }}$ & - & - & $5.6(1.2)^{a x}$ & $3.4(1.3)^{a x}$ \\
\hline Other forbs ${ }^{1}$ & - & - & $0.1(0.1)^{a x}$ & $0.1(0.1)^{a x}$ & - & - & $0.2(0.1)^{a x}$ & $0.0(0.0)^{a x}$ \\
\hline others & $0.3(0.1)^{\mathrm{aAx}}$ & $0.6(0.4)^{\mathrm{aAx}}$ & $0.7(0.2)^{\mathrm{aAx}}$ & $0.6(0.2)^{\mathrm{aAx}}$ & $0.8(0.3)^{\mathrm{aAx}}$ & $2.0(0.7)^{a B x}$ & $0.3(0.2)^{\mathrm{aAx}}$ & $0.2(0.1)^{\mathrm{aAx}}$ \\
\hline
\end{tabular}

${ }^{1}$ Salad burnet and caraway. ${ }^{a, b}$ Differences between the periods, according to the adjusted $p$-value method. ${ }^{\mathrm{A}, \mathrm{B}}$ Differences between treatments, according to the adjusted $p$-value method. ${ }^{x, y}$ Differences between offered and rest, according to the adjusted $p$-value method.

The daily methane emissions increased with the pasture diversity, and the mean values were $18 \%$ greater $(p<0.01)$ in diverse pastures, with mean values of 221 - and $260-\mathrm{g}$ $\mathrm{CH}_{4}$ day $^{-1}$ for the binary and diverse mixtures, respectively. The emissions generally decreased $(p<0.01)$ over time, with mean values of 258 - and $223-\mathrm{g} \mathrm{CH}_{4}$ day ${ }^{-1}$ for $\mathrm{P} 1$ and P2, respectively. The estimated DMI was unaffected by the pasture diversity for both periods, but they were $45 \%$ greater in P1 compared to P2. There was no significant treatment $\times$ period interaction for any of the fixed variables.

\subsection{Milk Yield, Milk Composition, and Methane Intensity}

The mean values for the methane emissions per kg ECM were $11 \%$ greater $(p<0.01)$ in the diverse, compared to binary, mixtures, with 9.8- and 8.8- $\mathrm{g} \mathrm{CH}_{4} \mathrm{~kg} \mathrm{ECM}^{-1}$ on average, respectively (Table 3 ). Over time, the methane intensity generally increased and was $11 \%$ lower $(p<0.05)$ in P1 compared to P2, with mean values of 8.8- and 9.9-g $\mathrm{CH}_{4} \mathrm{~kg} \mathrm{ECM}^{-1}$, respectively. As shown in Table 3, the milk yield and ECM yields increased when the cows grazed the diverse mixtures in both P1 and P2 $(+4 \%, p<0.001)$. The milk composition was also affected by the pasture diversity; while the fat and lactose contents decreased by $4.2 \%$ on average $(p<0.05)$, the protein decreased by $1.7 \%(p<0.001)$ when the diversity increased. Nevertheless, the yields of the milk solids were greater in cows grazing the diverse mixtures $(2.4 \%$ on average for fat and lactose and $4.8 \%$ for protein; $p<0.05$ ) as a result of the greater milk yields. Across the lactation stage, the milk solid contents generally decreased from P1 to P2 by $3 \%(p<0.001)$ as the days in milk (DIM) advanced.

The body weights were not affected by the treatments. However, cows lost weight during P1 $\left(-0.2 \mathrm{~kg} \mathrm{day}^{-1}\right)$, coinciding with the peak of lactation, and they gained weight $\left(+0.2 \mathrm{~kg} \mathrm{day}^{-1}\right)$ during P2. 


\section{Discussion \\ 4.1. Excellent Forage Quality Might Explain Generally High Milk Yields and Low Methane Intensities}

As stated, our results show that cows grazing the diverse pasture sward increased their ECM yield compared to the binary mixtures. However, generally, the milk yields were very high in both treatments. Accordingly, the mean values during P2 (DIM = 154) of 22.1- and $23.5-\mathrm{kg}$ ECM cow ${ }^{-1}$ day $^{-1}$ for the binary and diverse pastures, respectively, were greater than those reported for grazing Jersey cows in mid-lactation by Münger and Kreuzer [50] of 17.8-kg ECM cow ${ }^{-1}$ day $^{-1}$ at 161 DIM and by van Wyngaard et al. [51] of 13.8 - or $19.0-\mathrm{kg}$ ECM cow ${ }^{-1}$ day $^{-1}$ (without concentrate supplementation and with $4 \mathrm{~kg}$ of concentrate per day, respectively). They were, nevertheless, comparable to the milk yields of Jerseys fed total mixed ration (TMR) diets with $32 \%$ concentrate ad libitum of 22.9-23.4-kg ECM cow ${ }^{-1}$ day $^{-1}$ at 187 DIM [52]. This may be explained, at least in part, by the body weights of the Jerseys, which, in the latter study, were, on average, $469 \mathrm{~kg}$ and, therefore, similar to the $442 \mathrm{~kg}$ in the present study and much higher than the $354 \mathrm{~kg}$ of Münger and Kreuzer [50] or the $398 \mathrm{~kg}$ of van Wyngaard et al. [51]. The cows' mean BW, as an indicator of size, is one of the main drivers of the DMI (when comparing feeds with the same quality) and, consequently, of the methane emissions and milk yield. Nevertheless, the fact that the Jerseys in the present study, with being fed $2 \mathrm{~kg}$ of concentrate (approximately 13-15\% of the DMI), produced equal milk yields to Jerseys being fed a TMR with approximatively one-third of the concentrate, and having a greater BW indicates a forage of excellent quality was available in the pastures in general, as well as the cows having a high genetic potential for milk production.

The high forage quality and genetic potential of the Jersey cows is illustrated in the milk yield, and this can also explain, at least partially, the very low $\mathrm{CH}_{4}$ emissions and, particularly, the methane intensities. Generally, the $\mathrm{CH}_{4}$ emissions in the present study of 203-277-g $\mathrm{CH}_{4}$ cow $^{-1}$ day $^{-1}$ were similar to the values reported previously for Jersey cows, ranging from 258- to 321-g $\mathrm{CH}_{4}$ day $^{-1}$ [50,52]. However, when compared to cattle with similar BW, these emissions are substantially lower than the $\sim 400-\mathrm{g} \mathrm{CH}_{4}$ day $^{-1}$ reported by Jonker et al., 2019. Additionally, due to the very high milk yields of $29.8-\mathrm{kg} \mathrm{ECM} \mathrm{cow}^{-1}$ day $^{-1}$ and 22.8-kg ECM cow ${ }^{-1}$ day $^{-1}$, on average, during periods P1 and P2, respectively, the emissions per unit of milk were low, with 8.8-g $\mathrm{CH}_{4} \mathrm{~kg} \mathrm{ECM}$ and 9.8-g $\mathrm{CH}_{4} \mathrm{Cow}^{-1}$ day $^{-1}$, on average, for P1 and P2, respectively. These values were much lower than the previously reported 17.9- and 17.4- $\mathrm{g} \mathrm{CH}_{4} \mathrm{~kg} \mathrm{ECM}^{-1}$ for Jersey cows being fed 0 and $4 \mathrm{~kg}$ of concentrate, as reported by van Wyngaard et al. [51], and even lower than the 13.4-g $\mathrm{CH}_{4}$ $\mathrm{kg} \mathrm{ECM}{ }^{-1}$ reported for Jersey cows fed $61 \%$ of the concentrate [52]. Like the very high milk yields, these low emissions are a combined result of the genetic potential of the cows and the very high energy concentrations and organic matter digestibility of up to $12.5-\mathrm{MJ} \mathrm{ME}$ and $87.6 \%$, respectively. These high qualities were a result of the very high use intensity, where each sward was grazed eight to nine times per year, with regrowth periods of 7-15 days dependent on the regrowth rates and, thus, always providing young, leafy materials. Under this pasture management regime, the herbage generally has very low contents of fiber and has very high concentrations of water-soluble carbohydrates (WSC). This is also consistent with the findings for sheep, where the grazing of tetraploid ryegrasses exhibited $12 \%$ lower methane emissions compared to conventional ryegrass cultivars [53]. This was likely to be due, in part, to higher WSC concentrations, although WSC alone was not sufficient to explain the differences in methane emissions. Additionally, when the remaining statistical uncertainty is considered, the generally low methane emissions of the cows are in accordance with the observed very high milk yields and the excellent forage quality.

\subsection{Increasing Pasture Diversity Did Not Reduce Methane Emissions Further}

The aim of this study was to investigate the potential for botanically diverse mixtures when presented as sown swards in dairy systems to reduce the enteric $\mathrm{CH}_{4}$ intensity and, 
hence, to decrease the entire GHG emissions from the system relative to a binary perennial ryegrass-white clover sward. Our results showed that the $\mathrm{CH}_{4}$ emissions were greater for the cows grazing diverse swards. This was despite their content of species containing plant-specialized metabolites, especially tannins, which have repeatedly been shown in previous studies to result in lower $\mathrm{CH}_{4}$ emissions per kg DMI (e.g., Piluzza et al. [54]). The species examined in the present study were birdsfoot trefoil, which contains intermediate concentrations of condensed tannins and which has previously shown potential for ruminant production [35], and salad burnet, which has high concentrations of hydrolysable tannins [55]. Additionally, ribwort plantain and chicory were included, as these species have previously been shown to produce low in vitro methane emissions, despite their relatively low or no tannin concentrations [56]. In chicory, however, this effect was cultivar-dependent. The reason that the methane emissions were not reduced despite the inclusion of these herbs and legumes is likely due to the low proportions at which they were present in the grazed pastures. As shown in the study of Jonker et al. [57], which fed ribwort plantain and chicory in mixtures in vivo, even moderately low proportions of $13 \%$ and $15 \%$, respectively, were not sufficient to reduce the $\mathrm{CH}_{4}$ emissions compared to the freshly cut perennial ryegrass-white clover material. With the even lower proportions of species with anti-methanogenic potential in the present study (maxima of $7 \%, 8 \%$, and $9 \%$ for birdsfoot trefoil, chicory, and ribwort plantain, respectively), these clearly were insufficient to affect the $\mathrm{CH}_{4}$ emission from cows that grazed these swards. A drawback of the management intensity of the rotational grazing system with 9-10 grazing cycles per year in total is that the selected herbs were unable to persist. Thus, species such as birdsfoot trefoil and salad burnet are outcompeted by species that have a growth strategy that is able to adapt to greater grazing pressures, particularly perennial ryegrass but, also, red and white clover. Thus, herbs containing anti-methanogenic compounds will require either enhanced concentrations of tannins or will be an appropriate solution for grassland systems with lower grazing pressures, where (a) the forage quality is lower due to more fibrous material and, hence, the $\mathrm{CH}_{4}$ emissions would be greater to begin with, and (b) the proportions of the bioactive species can be greater, due to a more suitable use intensity.

The reasons for increased $\mathrm{CH}_{4}$ emissions from cows that grazed the diverse swards are likely to be a combination of two factors. Firstly, the diverse mixture swards had a lower OM digestibility, which was likely a result of increased structural carbohydrates. This is to be expected, due to the share of herbs rich in structural carbohydrates, such as ribwort plantain, and the temporal asynchrony between the species and the corresponding difficulty in utilizing all the species under optimal conditions, thus resulting in increased proportions of stem fractions in many species [58]. Greater contents of structural carbohydrates result in increased $\mathrm{CH}_{4}$ formation during fermentation in the rumen [59]. Secondly, cows grazing the botanically diverse pasture had greater DMI. This was apparent from the group intakes as calculated from the measurements of the offered and remaining biomass (Table 3). Despite the OM digestibility being less for the diverse swards, it is worth mentioning that it was still highly digestible, especially during P1. Although the most appropriate methodology for a precise determination of the individual DMI is generally the use of external markers, the regulations for organic systems prevented their use here. Thus, due to the large variability and uncertainties connected to the intake calculations from the measurements of the herbage on offer and the residues after grazing, and due to the inability of the method to enable accurate calculations of the individual intakes per cow, a dual approach was selected as the most suitable option for the present study. In this approach, the model developed by Gruber et al. [44] was used to estimate the individual intake and to be compared against the group intake estimates as derived by the cut samples of herbage on offer and the residues after grazing. This model has proven to be the most accurate estimation of DMI for systems with similar conditions to those used in this study. Despite the apparent inability of the model to detect differences in the forage intake of mixtures with only small variations in quality, as apparent from the very small differences in the estimated intake among the treatments, the estimated intake in general 
appears to be reasonable, given the amount of milk produced. However, the greater DMI of herbage from the diverse mixture sward may better explain the greater methane emissions and greater milk yields from the diverse mixtures. Thus, the measured intakes from the measurements in the pasture are likely to be a slight underestimation, while their semiquantitative differences offer a realistic explanation for the observed differences in the animal performances and emissions. Similarly, the DMI likely resulted in higher milk yields from the diverse pastures. Nevertheless, despite the potential differences in the DMI, these findings are also in accordance with Totty et al. [60], who found that milk yields increase when cows graze diverse pasture mixtures that include high-sugar ryegrass and white clover, chicory, plantain, and birdsfoot trefoil (thus being comparable to the diverse mixture in the present study) compared to either high-sugar ryegrass monocultures or binary mixtures of ryegrass and white clover. These greater milk yields of up to $15 \%$ were obtained despite the equal energy concentrations and were due to a higher nutrient use efficiency, with the nitrogen excretions being reduced by almost $20 \%$ [60].

\section{Conclusions}

The present study showed that dairy cows grazing sown grass-white clover and grassclover-herb leys based on highly improved perennial ryegrass cultivars achieve high milk production levels with low methane emissions per $\mathrm{kg}$ of ECM. These beneficial outcomes were achieved under high grazing pressure with short-interval rotational stocking and low external inputs, which ensured that a very high forage quality from young and leafy materials was maintained during the grazing periods. The management system provided a feed of high metabolizable energy value, and low methane emissions were likely a result of this very high forage quality. Contrary to our hypotheses, the addition to the grass-white clover mixture of low proportions of forbs that contain plant-specialized metabolites did not, under the conditions of this experiment, provide any additional benefits. Hence, further research is needed to identify whether different mixture strategies or lower grazing intensities are other options for an increased role of forbs in grazing systems for dairy cows.

Author Contributions: Conceptualization, C.S.M.; data curation, C.L., J.I.G., and C.K.; formal analysis, C.L., T.R., R.L., J.I.G., M.H. and C.S.M.; funding acquisition, R.L. and C.S.M.; investigation, C.L.; methodology, C.L., T.R., and J.I.G.; project administration, C.S.M.; supervision, F.T.; validation: M.H., J.I.G. visualization, C.S.M.; writing-original draft, C.L.; and writing-review and editing, T.R., R.L., C.K., and C.S.M. All authors have read and agreed to the published version of the manuscript.

Funding: This research was made possible by funding from SusAn, an ERA-Net co-funded under European Union's Horizon 2020 research and innovation program (www.era-susan.eu, accessed on 19 Febraury 2021), Grant Agreement no. 696231, and the Federal Ministry of Food and Agriculture, Germany, Grant Agreement no. 2817ERA13D.

Institutional Review Board Statement: Not applicable.

Informed Consent Statement: Not applicable.

Data Availability Statement: The data presented in this study are available on request from the corresponding author.

Acknowledgments: We acknowledge financial support by DFG within the funding programme Open Access Publizieren. Thanks are addressed to Thomas Ehmsen and Petra Voß for their invaluable support in the fieldwork and laboratory tasks. The authors also thankfully acknowledge Sabine Mues and Keanu Heuck for sharing their facilities and technical support.

Conflicts of Interest: The authors declare that they have no known competing financial interests or personal relationships that could have appeared to influence the work reported in this paper. 


\section{Appendix A}

Table A1. Statistical data of the NIRS calibration and validation (SEC, standard error of calibration; SEV, standard error of prediction) for the relevant quality parameters by plant group.

\begin{tabular}{|c|c|c|c|c|c|c|c|}
\hline Parameter & $\begin{array}{l}\text { Plant } \\
\text { Group }\end{array}$ & $\mathbf{N}$ & Mean & Range & SEC & $\mathbf{R}^{2}$ & SEP \\
\hline $\begin{array}{c}\mathrm{ME}(\mathrm{MJ} / \mathrm{kg} \\
\mathrm{DM})\end{array}$ & $\begin{array}{l}\text { whole } \\
\text { sward }\end{array}$ & 251 & 10.810 & $8.38-12.62$ & 0.179 & 0.959 & 0.195 \\
\hline $\begin{array}{c}\mathrm{ME}(\mathrm{MJ} / \mathrm{kg} \\
\mathrm{DM})\end{array}$ & Grasses & 248 & 10.806 & $8.38-12.62$ & 0.173 & 0.956 & 0.194 \\
\hline & $\begin{array}{l}\text { Legumes } \\
\text { Herbs }\end{array}$ & $\begin{array}{l}168 \\
117\end{array}$ & $\begin{array}{l}10.737 \\
10.691\end{array}$ & $\begin{array}{l}8.55-12.41 \\
8.38-12.54\end{array}$ & $\begin{array}{c}0.15 \\
0.154\end{array}$ & $\begin{array}{l}0.961 \\
0.963\end{array}$ & $\begin{array}{l}0.196 \\
0.211\end{array}$ \\
\hline $\begin{array}{c}\text { NEL }(M J / k g \\
\text { DM) }\end{array}$ & $\begin{array}{l}\text { whole } \\
\text { sward }\end{array}$ & 249 & 6.567 & $4.79-7.81$ & 0.138 & 0.955 & 0.173 \\
\hline $\begin{array}{c}\text { NEL }(\mathrm{MJ} / \mathrm{kg} \\
\text { DM) }\end{array}$ & Grasses & 250 & 6.569 & $4.79-7.87$ & 0.136 & 0.949 & 0.193 \\
\hline & $\begin{array}{c}\text { Legumes } \\
\text { Herbs }\end{array}$ & $\begin{array}{l}167 \\
115\end{array}$ & $\begin{array}{l}6.512 \\
6.514\end{array}$ & $\begin{array}{c}4.92-7.77 \\
4.80-7.784\end{array}$ & $\begin{array}{l}0.106 \\
0.112\end{array}$ & $\begin{array}{l}0.965 \\
0.964\end{array}$ & $\begin{array}{l}0.152 \\
0.163\end{array}$ \\
\hline $\begin{array}{c}\mathrm{DOM}(\mathrm{g} / \mathrm{kg} \\
\mathrm{DM})\end{array}$ & $\begin{array}{l}\text { whole } \\
\text { sward }\end{array}$ & 249 & 809.45 & $642.6-919.0$ & 8.85 & 0.967 & 9.14 \\
\hline $\begin{array}{c}\mathrm{DOM}(\mathrm{g} / \mathrm{kg} \\
\mathrm{DM})\end{array}$ & Grasses & 248 & 821.04 & 632.1-918.8 & 10.83 & 0.956 & 10.97 \\
\hline & $\begin{array}{l}\text { Legumes } \\
\text { Herbs }\end{array}$ & $\begin{array}{l}173 \\
118\end{array}$ & $\begin{array}{l}803.63 \\
817.42\end{array}$ & $\begin{array}{l}657.6-902.6 \\
642.6-904.3\end{array}$ & $\begin{array}{l}10.36 \\
13.51\end{array}$ & $\begin{array}{l}0.944 \\
0.943\end{array}$ & $\begin{array}{l}12.96 \\
12.45\end{array}$ \\
\hline $\mathrm{N}(\mathrm{g} / \mathrm{kg} \mathrm{DM})$ & $\begin{array}{l}\text { whole } \\
\text { sward }\end{array}$ & 268 & 26.69 & $8.7-54.2$ & 0.951 & 0.991 & 1.071 \\
\hline $\mathrm{N}(\mathrm{g} / \mathrm{kg} \mathrm{DM})$ & $\begin{array}{l}\text { Grasses } \\
\text { legumes } \\
\text { herbs }\end{array}$ & $\begin{array}{c}277 \\
178 \\
86\end{array}$ & $\begin{array}{l}22.59 \\
35.07 \\
26.39\end{array}$ & $\begin{array}{c}9-54.9 \\
14.7-57.1 \\
10.3-39.9\end{array}$ & $\begin{array}{l}0.802 \\
1.116 \\
0.749\end{array}$ & $\begin{array}{l}0.991 \\
0.981 \\
0.995\end{array}$ & $\begin{array}{l}0.914 \\
1.131 \\
1.317\end{array}$ \\
\hline
\end{tabular}

\section{References}

1. Martin, C.; Morgavi, D.P.; Doreau, M. Methane mitigation in ruminants: From microbe to the farm scale. Animal 2010, 4, 351-365. [CrossRef]

2. McAllister, T.A.; Newbold, C.J. Redirecting rumen fermentation to reduce methanogenesis. Aust. J. Exp. Agric. 2008, 48, 7-13. [CrossRef]

3. Gerber, P.J.; Steinfeld, H.; Henderson, B.; Mottet, A.; Opio, C.; Dijkman, J.; Falcucci, A.; Tempio, G. Tackling Climate Change through Livestock-A Global Assessment of Emissions and Mitigation Opportunities; Food and Agriculture Orginazion of the United Nations (FAO): Rome, Italy, 2013; p. 139. Available online: http:/ / www.fao.org/3/i3437e/i3437e.pdf (accessed on 6 November 2020).

4. Thorpe, A. Enteric fermentation and ruminant eructation: The role (and control?) of methane in the climate change debate. Clim. Chang. 2009, 93, 407-431. [CrossRef]

5. Conant, R.T.; Paustian, K.; Elliott, E.T. Grassland management and conversion into grassland: Effects on soil carbon. Ecol. Appl. 2001, 11, 343-355. [CrossRef]

6. O'Mara, F.P. The significance of livestock as a contributor to global greenhouse gas emissions today and in the near future. Anim. Feed Sci. Technol. 2011, 166, 7-15. [CrossRef]

7. Elgersma, A. Grazing increases the unsaturated fatty acid concentration of milk from grass-fed cows: A review of the contributing factors, challenges and future perspectives. Eur. J. Lipid Sci. Technol. 2015, 117, 1345-1369. [CrossRef]

8. Fruet, A.P.B.; Trombetta, F.; Stefanello, F.S.; Speroni, C.S.; Donadel, J.Z.; De Souza, A.N.M.; Rosado Júnior, A.; Tonetto, C.J.; Wagner, R.; De Mello, A.; et al. Effects of feeding legume-grass pasture and different concentrate levels on fatty acid profile, volatile compounds, and off-flavor of the M. longissimus thoracis. Meat Sci. 2018, 140, 112-118. [CrossRef]

9. Koba, K.; Yanagita, T. Health benefits of conjugated linoleic acid (CLA). Obes. Res. Clin. Pract. 2014, 8, e525-e532. [CrossRef] [PubMed]

10. Peyraud, J.L.; Pol, A.v.d.; Dillon, P.; Delaby, L. Producing milk from grazing to reconcile economic and environmental performances. In Proceedings of the 23th General Meeting of the European Grassland Federation, Kiel, Germany, 29 August-2 September 2010; pp. 163-164. Available online: https:/ / www.europeangrassland.org/en/infos/printed-matter/proceedings.html (accessed on 6 November 2020).

11. Thomet, P.; Cutullic, E.; Bisig, W.; Wuest, C.; Elsaesser, M.; Steinberger, S.; Steinwidder, A. Merits of full grazing systems as a sustainable and efficient milk production strategy. In Proceedings of the 16th Symposium of the European Grassland Federation, 
Gumpenstein, Austria, 29-31 August 2011; pp. 273-285. Available online: https://www.europeangrassland.org/en/infos/ printed-matter/proceedings.html (accessed on 5 October 2020).

12. Kühl, S.; Gassler, B.; Spiller, A. Labeling strategies to overcome the problem of niche markets for sustainable milk products: The example of pasture-raised milk. J. Dairy Sci. 2017, 100, 5082-5096. [CrossRef] [PubMed]

13. Weinrich, R.; Kühl, S.; Zühlsdorf, A.; Spiller, A. Consumer Attitudes in Germany towards Different Dairy Housing Systems and Their Implications for the Marketing of Pasture Raised Milk. Int. Food Agribus. Manag. Rev. 2014, 17, 205-222. [CrossRef]

14. Decruyenaere, V.; Buldgen, A.; Stilmant, D. Factors affecting intake by grazing ruminants and related quantification methods: A review. Biotechnol. Agron. Soc. Environ. 2009, 13, 559-573. Available online: https:/ / popups.uliege.be/1780-4507/index.php? $\mathrm{id}=4757$ (accessed on 10 December 2020).

15. Holter, J.B.; West, J.W.; McGilliard, M.L. Predicting Ad Libitum Dry Matter Intake and Yield of Holstein Cows1. J. Dairy Sci. 1997, 80, 2188-2199. [CrossRef]

16. Mertens, D.R. Predicting Intake and Digestibility Using Mathematical Models of Ruminal Function. J. Anim. Sci. 1987, 64, 15481558. [CrossRef] [PubMed]

17. Ueda, K.; Mitani, T.; Kondo, S. Herbage intake and ruminal digestion of dairy cows grazed on perennial ryegrass pasture either in the morning or evening. Anim. Sci. J. 2016, 87, 997-1004. [CrossRef]

18. Vazquez, O.P.; Smith, T.R. Factors Affecting Pasture Intake and Total Dry Matter Intake in Grazing Dairy Cows. J. Dairy Sci. 2000, 83, 2301-2309. [CrossRef]

19. Peyraud, J.L.; Delagarde, R. Managing variations in dairy cow nutrient supply under grazing. Animal 2013, 7, 57-67. [CrossRef] [PubMed]

20. Wachendorf, M.; Büchter, M.; Trott, H.; Taube, F. Performance and environmental effects of forage production on sandy soils. II. Impact of defoliation system and nitrogen input on nitrate leaching losses. Grass Forage Sci. 2004, 59, 56-68. [CrossRef]

21. Muñoz, C.; Letelier, P.A.; Ungerfeld, E.M.; Morales, J.M.; Hube, S.; Pérez-Prieto, L.A. Effects of pregrazing herbage mass in late spring on enteric methane emissions, dry matter intake, and milk production of dairy cows. J. Dairy Sci. 2016, 99, 7945-7955. [CrossRef]

22. Wims, C.M.; Deighton, M.H.; Lewis, E.; O’Loughlin, B.; Delaby, L.; Boland, T.M.; O’Donovan, M. Effect of pregrazing herbage mass on methane production, dry matter intake, and milk production of grazing dairy cows during the mid-season period1. J. Dairy Sci. 2010, 93, 4976-4985. [CrossRef] [PubMed]

23. Lorenz, H.; Reinsch, T.; Hess, S.; Taube, F. Is low-input dairy farming more climate friendly? A meta-analysis of the carbon footprints of different production systems. J. Clean. Prod. 2019, 211, 161-170. [CrossRef]

24. Leip, A.; Weiss, F.; Wasenaar, T.; Perez, I.; Fellmann, T.; Loudjami, P.; Tuiello, F.; Grandgirard, D.; Monni, S.; Biala, K. Evaluation of the Livestock Sector's Contribution to the EU Greenhouse Gas Emissions (GGELS)—Final Report; European Commission, Joint Research Centre: Ispra, Italy, 2010; Available online: https: / op.europa.eu/s/oMkr (accessed on 5 January 2021).

25. Beauchemin, K.A.; Ungerfeld, E.M.; Eckard, R.J.; Wang, M. Review: Fifty years of research on rumen methanogenesis: Lessons learned and future challenges for mitigation. Animal 2020, 14, s2-s16. [CrossRef]

26. Jayanegara, A.; Leiber, F.; Kreuzer, M. Meta-analysis of the relationship between dietary tannin level and methane formation in ruminants from in vivo and in vitro experiments. J. Anim. Physiol. Anim. Nutr. 2012, 96, 365-375. [CrossRef]

27. Min, B.R.; Solaiman, S.; Waldrip, H.M.; Parker, D.; Todd, R.W.; Brauer, D. Dietary mitigation of enteric methane emissions from ruminants: A review of plant tannin mitigation options. Anim. Nutr. 2020. [CrossRef] [PubMed]

28. Patra, A.K. Recent Advances in Measurement and Dietary Mitigation of Enteric Methane Emissions in Ruminants. Front. Vet. Sci. 2016, 3, 39. [CrossRef] [PubMed]

29. Adamczyk, B.; Karonen, M.; Adamczyk, S.; Engström, M.T.; Laakso, T.; Saranpää, P.; Kitunen, V.; Smolander, A.; Simon, J. Tannins can slow-down but also speed-up soil enzymatic activity in boreal forest. Soil Biol. Biochem. 2017, 107, 60-67. [CrossRef]

30. Kagiya, N.; Reinsch, T.; Taube, F.; Salminen, J.-P.; Kluß, C.; Hasler, M.; Malisch, C.S. Turnover rates of roots vary considerably across temperate forage species. Soil Biol. Biochem. 2019, 139, 107614. [CrossRef]

31. Mueller-Harvey, I.; Bee, G.; Dohme-Meier, F.; Hoste, H.; Karonen, M.; Kölliker, R.; Lüscher, A.; Niderkorn, V.; Pellikaan, W.F.; Salminen, J.-P.; et al. Benefits of Condensed Tannins in Forage Legumes Fed to Ruminants: Importance of Structure, Concentration, and Diet Composition. Crop Sci. 2019, 59, 861-885. [CrossRef]

32. Aerts, R.J.; Barry, T.N.; McNabb, W.C. Polyphenols and agriculture: Beneficial effects of proanthocyanidins in forages. Agric. Ecosyst. Environ. 1999, 75, 1-12. [CrossRef]

33. Min, B.R.; Barry, T.N.; Attwood, G.T.; McNabb, W.C. The effect of condensed tannins on the nutrition and health of ruminants fed fresh temperate forages: A review. Anim. Feed Sci. Technol. 2003, 106, 3-19. [CrossRef]

34. Mueller-Harvey, I. Unravelling the conundrum of tannins in animal nutrition and health. J. Sci. Food Agric. 2006, 86, 2010-2037. [CrossRef]

35. Waghorn, G. Beneficial and detrimental effects of dietary condensed tannins for sustainable sheep and goat production-Progress and challenges. Anim. Feed Sci. Technol. 2008, 147, 116-139. [CrossRef]

36. Lee, M.R.F. Forage polyphenol oxidase and ruminant livestock nutrition. Front. Plant Sci. 2014, 5, 694. [CrossRef] [PubMed]

37. Nyfeler, D.; Huguenin-Elie, O.; Suter, M.; Frossard, E.; Connolly, J.; Luscher, A. Strong mixture effects among four species in fertilized agricultural grassland led to persistent and consistent transgressive overyielding. J. Appl. Ecol. 2009, 46, 683-691. [CrossRef] 
38. Hofer, D.; Suter, M.; Haughey, E.; Finn John, A.; Hoekstra Nyncke, J.; Buchmann, N.; Lüscher, A. Yield of temperate forage grassland species is either largely resistant or resilient to experimental summer drought. J. Appl. Ecol. 2016, 53, 1023-1034. [CrossRef]

39. Hungate, B.A.; Barbier, E.B.; Ando, A.W.; Marks, S.P.; Reich, P.B.; van Gestel, N.; Tilman, D.; Knops, J.M.H.; Hooper, D.U.; Butterfield, B.J.; et al. The economic value of grassland species for carbon storage. Sci. Adv. 2017, 3, e1601880. [CrossRef]

40. Naumann, H.; Sepela, R.; Rezaire, A.; Masih, S.E.; Zeller, W.E.; Reinhardt, L.A.; Robe, J.T.; Sullivan, M.L.; Hagerman, A.E. Relationships between Structures of Condensed Tannins from Texas Legumes and Methane Production During In Vitro Rumen Digestion. Molecules 2018, 23, 2123. [CrossRef] [PubMed]

41. Aboagye, I.A.; Oba, M.; Castillo, A.R.; Koenig, K.M.; Iwaasa, A.D.; Beauchemin, K.A. Effects of hydrolyzable tannin with or without condensed tannin on methane emissions, nitrogen use, and performance of beef cattle fed a high-forage diet1,2. J. Anim. Sci. 2018, 96, 5276-5286. [CrossRef]

42. Gere, J.I.; Gratton, R. Simple, low-cost flow controllers for time averaged atmospheric sampling and other applications. Lat. Am. Appl. Res. 2010, 40, 377-381. Available online: https:/ / www.researchgate.net/publication/258311874 (accessed on 12 June 2019 ).

43. Belanche, A.; Kingston-Smith, A.H.; Griffith, G.W.; Newbold, C.J. A Multi-Kingdom Study Reveals the Plasticity of the Rumen Microbiota in Response to a Shift From Non-grazing to Grazing Diets in Sheep. Front. Microbiol. 2019, 10, 122. [CrossRef] [PubMed]

44. Gruber, L.; Schwarz, F.; Erdin, D.; Fischer, B.; Spiekers, H.; Steingass, H.; Meyer, U.; Chassot, A.; Jilg, T.; Obermaier, A. Vorhersage der Futteraufnahme von Milchkühen-Datenbasis von 10 Forschungs-und Universitätsinstituten Deutschlands, Österreichs und der Schweiz. VDLUFA-Schriftenreihe 2004, 60, 484-504.

45. Jensen, L.M.; Nielsen, N.I.; Nadeau, E.; Markussen, B.; Nørgaard, P. Evaluation of five models predicting feed intake by dairy cows fed total mixed rations. Livest. Sci. 2015, 176, 91-103. [CrossRef]

46. Sjaunja, L. A Nordic proposal for an energy-corrected milk (ECM) formula. In Proceedings of the 27th Session International Committee for Recording and Productivity of Milk Animals, Paris, France, 2-6 July 1990; Available online: https:/ / popups. uliege.be /1780-4507/index.php?id=4757 (accessed on 3 June 2020).

47. Berndt, A.; Boland, T.M.; Deighton, M.H.; Gere, J.I.; Grainger, C.; Hegarty, R.S.; Iwaasa, A.D.; Koolaard, J.P.; Lassey, K.R.; Luo, D.; et al. Guidelines for Use of Sulphur Hexafluoride (SF 6) Tracer Technique to Measure Enteric Methane Emissions from Ruminants; New Zealand Agricultural Greenhouse Gas Research Centre: Palmerston North, New Zealand, 2014; p. 166. [CrossRef]

48. De Boever, J.L.; Cottyn, B.G.; Andries, J.I.; Buysse, F.X.; Vanacker, J.M. The use of a cellulase technique to predict digestibility, metabolizable and net energy of forages. Anim. Feed Sci. Technol. 1988, 19, 247-260. [CrossRef]

49. R Core Team. R: A language and environment for statistical computing. R Foundation for Statistical Computing; R Foundation for Statistical Computing: Vienna, Austria, 2020.

50. Münger, A.; Kreuzer, M. Methane emission as determined in contrasting dairy cattle breeds over the reproduction cycle. Int. Congr. Ser. 2006, 1293, 119-122. [CrossRef]

51. van Wyngaard, J.D.V.; Meeske, R.; Erasmus, L.J. Effect of concentrate feeding level on methane emissions, production performance and rumen fermentation of Jersey cows grazing ryegrass pasture during spring. Anim. Feed Sci. Technol. 2018, 241, 121-132. [CrossRef]

52. Olijhoek, D.W.; Løvendahl, P.; Lassen, J.; Hellwing, A.L.F.; Höglund, J.K.; Weisbjerg, M.R.; Noel, S.J.; McLean, F.; Højberg, O.; Lund, P. Methane production, rumen fermentation, and diet digestibility of Holstein and Jersey dairy cows being divergent in residual feed intake and fed at 2 forage-to-concentrate ratios. J. Dairy Sci. 2018, 101, 9926-9940. [CrossRef]

53. Jonker, A.; Molano, G.; Sandoval, E.; Taylor, P.S.; Antwi, C.; Olinga, S.; Cosgrove, G.P. Methane emissions differ between sheep offered a conventional diploid, a high-sugar diploid or a tetraploid perennial ryegrass cultivar at two allowances at three times of the year. Anim. Prod. Sci. 2016, 58, 1043-1048. [CrossRef]

54. Piluzza, G.; Sulas, L.; Bullitta, S. Tannins in forage plants and their role in animal husbandry and environmental sustainability: A review. Grass Forage Sci. 2014, 69, 32-48. [CrossRef]

55. Finimundy, T.C.; Karkanis, A.; Fernandes, Â.; Petropoulos, S.A.; Calhelha, R.; Petrović, J.; Soković, M.; Rosa, E.; Barros, L.; Ferreira, I.C.F.R. Bioactive properties of Sanguisorba minor L. cultivated in central Greece under different fertilization regimes. Food Chem. 2020, 327, 127043. [CrossRef]

56. Durmic, Z.; Moate, P.J.; Jacobs, J.L.; Vadhanabhuti, J.; Vercoe, P.E. In vitro fermentability and methane production of some alternative forages in Australia. Anim. Prod. Sci. 2016, 56, 641-645. [CrossRef]

57. Jonker, A.; Farrell, L.; Scobie, D.; Dynes, R.; Edwards, G.; Hague, H.; McAuliffe, R.; Taylor, A.; Knight, T.; Waghorn, G. Methane and carbon dioxide emissions from lactating dairy cows grazing mature ryegrass/white clover or a diverse pasture comprising ryegrass, legumes and herbs. Anim. Prod. Sci. 2018, 59, 1063-1069. [CrossRef]

58. Bruinenberg, M.H.; Valk, H.; Korevaar, H.; Struik, P.C. Factors affecting digestibility of temperate forages from seminatural grasslands: A review. Grass Forage Sci. 2002, 57, 292-301. [CrossRef]

59. Boadi, D.A.; Wittenberg, K.M. Methane production from dairy and beef heifers fed forages differing in nutrient density using the sulphur hexafluoride (SF6) tracer gas technique. Can. J. Anim. Sci. 2002, 82, 201-206. [CrossRef]

60. Totty, V.K.; Greenwood, S.L.; Bryant, R.H.; Edwards, G.R. Nitrogen partitioning and milk production of dairy cows grazing simple and diverse pastures. J. Dairy Sci. 2013, 96, 141-149. [CrossRef] [PubMed] 